\title{
Renal cancer-selective Englerin A induces multiple mechanisms of cell death and autophagy
}

Richard T Williams ${ }^{1}$, Alice L Yu ${ }^{1,2,3}$, Mitchell B Diccianni ${ }^{1}$, Emmanuel A Theodorakis ${ }^{4}$ and Ayse Batova ${ }^{4 *}$

\begin{abstract}
Renal cell carcinoma (RCC), the most common malignancy of the kidney, is refractory to standard therapy and has an incidence that continues to rise. Screening of plant extracts in search of new agents to treat RCC resulted in the discovery of englerin A (EA), a natural product exhibiting potent selective cytotoxicity against renal cancer cells. Despite the establishment of synthetic routes to the synthesis of EA, very little is known about its mechanism of action. The results of the current study demonstrate for the first time that EA induces apoptosis in A498 renal cancer cells in addition to necrosis. The induction of apoptosis by EA required at least $24 \mathrm{~h}$ and was caspase independent. In addition, EA induced increased levels of autophagic vesicles in A498 cells which could be inhibited by nonessential amino acids (NEAA), known inhibitors of autophagy. Interestingly, inhibition of autophagy by NEAA did not diminish cell death suggesting that autophagy is not a cell death mechanism and likely represents a cell survival mechanism which ultimately fails. Apart from cell death, our results demonstrated that cells treated with EA accumulated in the $\mathrm{G}_{2}$ phase of the cell cycle indicating a block in $\mathrm{G}_{2} / \mathrm{M}$ transition. Moreover, our results determined that EA inhibited the activation of both AKT and ERK, kinases which are activated in cancer and implicated in unrestricted cell proliferation and induction of autophagy. The phosphorylation status of the cellular energy sensor, AMPK, appeared unaffected by EA. The high renal cancer selectivity of EA combined with its ability to induce multiple mechanisms of cell death while inhibiting pathways driving cell proliferation, suggest that EA is a highly unique agent with great potential as a therapeutic lead for the treatment of RCC.
\end{abstract}

Keywords: Englerin A, Apoptosis, Autophagy, Necrosis, Renal cell carcinoma

\section{Introduction}

Renal cell carcinoma (RCC) is the most common type of malignant kidney tumor with an incidence that continues to rise. Between 1992 and 2005, the incidence of RCC rose by $1.8 \%$ and $2.1 \%$ among white men and white women, respectively [1]. Although surgery can be curative for tumors confined to the kidney, about $25 \%$ of patients have metastatic disease at diagnosis, and another $20-40 \%$ develop metastases following surgery $[2,3]$. The two-year survival rate for patients with metastatic disease is under $20 \%$ due to the poor response of these tumors to current treatments. Clear cell RCC (cc-RCC) which comprises $83 \%$ of $\mathrm{RCC}$ is one of the most radio-

\footnotetext{
* Correspondence: abatova@ucsd.edu

${ }^{4}$ Department of Chemistry and Biochemistry, University of California, 9500 Gilman Drive, La Jolla, CA 92093, USA

Full list of author information is available at the end of the article
}

and chemo-resistant cancers and no curative treatment is available once metastases develop [4].

Investigations of the molecular biology of RCC have established that inactivating alterations in the Von Hippel Lindau (VHL) tumor suppressor gene are present in the majority (91\%) of sporadic cc-RCC underscoring the central role of VHL in the regulation of growth and differentiation of renal epithelium [5-7]. The VHL gene product is involved in oxygen and energy sensing by regulating the activity of the hypoxia inducible factors (HIFs) [8]. Inactivation of VHL results in HIF stabilization and the activation of transcription of over 60 hypoxiaresponsive genes involved in oncogenesis and tumor progression including vascular endothelial growth factor (VEGF), the platelet-derived growth factor (PDGF), transforming growth factor alpha (TGF- $\alpha$ ), epidermal growth factor (EGF), and glucose transporter-1 (GLUT-1) 
among others $[9,10]$. Subsequent to the activation of HIFinducible genes, a variety of downstream signaling pathways are activated of which the most studied are the RAF-MEK-ERK series of kinases and the phosphatidylinositol3 kinase-protein kinase B-mammalian target of rapamycin (PI3K-AKT-mTOR) pathway [11]. Based on the activation of these pathways in RCC, several targeted therapies have been developed including those against VEGF and PDGF receptors, and mTOR. However, despite the promise of approved targeted therapies for RCC, a complete response is rare and patients often become resistant/refractory to first line treatment $[3,12]$. Thus, new agents with improved efficacy and decreased toxicity are needed as treatment options in first line or subsequent settings.

The need to identify new chemical motifs as potential drug leads has spurred the screening of plant extracts that are being used in traditional medicines $[13,14]$. In particular, South Africa has a remarkable botanical diversity with over 30,000 flowering species, from which more than 3,000 are used for medicinal purposes throughout the country. Among them, plants of the genus Phyllanthus (Euphorbiaceae) are widely distributed in tropical forests throughout the world and have long been used in folk medicine to treat kidney and urinary tract infections [15]. Based on this knowledge, Ratnayake et al. [16] at the NCI screened extracts of the Tanzanian plant Phyllanthus engleri and have reported the isolation of two novel bioactive sesquiterpenes, named englerin A (EA) and englerin B. Initial studies by the NCI demonstrated that EA possessed very potent growth inhibitory activity $\left(\mathrm{GI}_{50}=10-87 \mathrm{nM}\right)$ against most RCC with a selectivity that is approximately 1,000-fold higher compared to other cancers.

Although several synthetic routes toward the synthesis of EA have been established [16-21], other than EA's selective toxicity to $\mathrm{RCC}$, recently confirmed by us [21], very little is known about its biological actions and mechanism(s) of action. Only recently, one study reported that EA induced necrosis in RCC [22]. The most recent report concluded that EA bound and activated protein kinase $\mathrm{C}-\theta$ (PKC $\theta)$ to inhibit insulin signaling while, concurrently, activating HSF1, a known inducer of glucose dependence [23]. This dual signaling, that promotes glucose addiction while inhibiting glucose uptake by the cells, was proposed to be the mechanism for the selective cytotoxicity of EA. Although the data presented is compelling, whether in fact this mechanism accounts for the cytotoxicity of EA is not yet clear. Based on its cytotoxicity profile against the NCI60 cell panel, EA is clearly a very unique agent and there is much to be learned about the actions of EA in RCC and the mechanisms and targets involved in these actions. In this study, using the highly EA-sensitive A498 human renal carcinoma cells as our model system, we report the results of a thorough and systematic investigation to uncover the mechanisms of growth inhibition and cell death induced by EA and reveal for the first time that EA induces multiple mechanisms of cell death as well as cell cycle arrest while inducing autophagy.

\section{Material and methods \\ Cell lines}

The A498 human kidney carcinoma cell line was purchased from ATCC and maintained in RPMI medium supplemented with $10 \%$ FBS and 100 units $/ \mathrm{ml}$ penicillin/streptomycin (complete medium).

\section{Reagents}

Englerin A was purchased from Cerilliant Corporation. (Round Rock, Texas). Rapamycin was purchased from Enzo Life Sciences (Farmingdale, NY) as part of the Cyto-ID ${ }^{\ominus}$ Autophagy Detection Kit. VP16 was purchased from Sigma Aldrich (St. Louis, MO). MEM 100X nonessential amino acids (NEAA) was purchased from Gibco Life Technologies (Grand Island, NY). Antibody against caspase-3 was a gift from Dr. Robert Naviaux and anti LC3B was purchased from Cell Signaling Technology (Danvers, MA). Antibody against B-actin (AC-15) was purchased from Sigma Aldrich (St. Louis, MO). Antibodies against phospho AMPK (Thr172) and phospho ERK (Thr202/Tyr204) as well as those for AMPK and ERK were generous gifts of Dr. R. Naviaux. The antibodies against AKT and phospho AKT (Ser473) were purchased from Cell Signaling Technology.

\section{Viability assay}

A498 cells were plated at 5,000 cells/well in a 96-well plate in complete medium. The following day, cells were treated with EA at 50 and $100 \mathrm{nM}$. Control cells received $0.1 \%$ DMSO. All conditions were performed in triplicate. Cells were then incubated with additions for 24 or $48 \mathrm{~h}$ before measuring viability using the PrestoBlue ${ }^{\circ}$ (Invitrogen, CA) assay as described by manufacturer. This assay uses a resazurin-based solution that functions as a cell viability indicator by using the reducing power of living cells to quantitatively measure the proliferation of cells. Viability was determined by measuring fluorescence on a Synergy Mx plate reader (BioTek Instruments Inc., Winooski, VT) with excitation/emission at 560/590 nM.

\section{Apoptosis assays}

Apoptosis was determined independently by two different methods. The Alexa Fluor ${ }^{\circledR} 48$ annexin V/Dead Cell Apoptosis Kit (Life Technologies, Grand Island, NY) was used to measure externalized phosphatidyl serine and dead cells permeable to propidium iodide (PI). For these experiments, A498 cells were treated with 100 nM EA 
or with $0.1 \%$ DMSO (control) for 24 and 46 h. Cells were then trypsinized, washed with ice cold PBS, and stained with Alexa Fluor 488 annexin V and PI as recommended by manufacturer. Cells were then analyzed by flow cytometry using a FACS Caliber flow cytometer (Beckton Dickinson, Franklin Lakes, NJ) and Flow Jo software (TreeStar Inc., Ashland, OR).

Apoptosis induced by EA in A498 cells was also determined by measuring cytoplasmic histone-associated-DNAfragments using the Cell Death Detection ELISAPLUS kit (Roche Diagnostics GmbH, Mannheim, Germany) according to the manufacturer's instructions. In these experiments, A498 cells were plated at 5,000 cells/well (96well plate) in complete RPMI medium. The following day, cells were treated with $100 \mathrm{nM}$ EA or with $0.1 \%$ DMSO, and incubated at $37^{\circ} \mathrm{C}$ for 18,24 , and $45 \mathrm{~h}$ before apoptosis was measured.

\section{Caspase assays}

Multiple caspases were analyzed using the FLICA reagent (FAM Caspase Activity kit, Imgenex, San Diego, CA) which only binds active caspases. In these experiments, A498 cells were plated at $0.5 \times 10^{6}$ cells/T-25 flask in complete RPMI. After cells were allowed to attach overnight, cells were treated with $100 \mathrm{nM}$ EA or $0.1 \%$ DMSO for $43 \mathrm{~h}$, or with $200 \mu \mathrm{M}$ etoposide for 24 h. Cells were then harvested and stained with the FLICA reagent according to manufacturer's recommendations and fluorescence was measured with excitation at 490 $\mathrm{nm}$ and emission at $520 \mathrm{~nm}$. Caspase- 9 activity was measured after treatment of cells with and without 100 nM EA as above followed by trypsinization and cell lysis. Caspase-9 activity was then determined using the Caspase-9 Colorimetric Assay kit (BioVision, Mountain View, CA) according to protocol provided by manufacturer. Absorbance was read at $400 \mathrm{~nm}$. The levels of active caspase- 3 were determined by Western blot analysis as described below.

\section{Autophagy assays}

Autophagy was determined by three different methods including flow cytometry, fluorescence microscopy and western blot analysis. For flow cytometry experiments, A498 cells were plated in T-75 flasks at $1.25 \times 10^{6} /$ flask in complete RPMI. After the cells were allowed to attach overnight, cell were treated with $200 \mathrm{nM}$ EA or $0.1 \%$ DMSO (control) for $46 \mathrm{~h}$ and with $500 \mathrm{nM}$ rapamycin for $20 \mathrm{~h}$. Autophagy was measured by staining autolysosomes and earlier autophagic compartments with the fluorescent probe Cyto-ID ${ }^{\circ}$ Green (Enzo Life Sciences, Farmingdale, NY) as recommended by manufacturer. Samples were then analyzed in the green (FL1) channel of the FACS Caliber flow cytometer.
For fluorescence microscopy, A498 cells were plated in complete RPMI on coverslips placed in a $60 \mathrm{~mm}$ dish at 1.5 (control cells) to $3.0 \times 10^{5}$ (treated cells) cells/dish. After the cells were allowed to attach overnight, cell were treated with $200 \mathrm{nM}$ EA or $0.1 \%$ DMSO (control) for $45 \mathrm{~h}$. Cells were then stained with Hoechst nuclear stain and Cyto-ID ${ }^{\circ}$ Green detection reagent using the Cyto-ID ${ }^{\circ}$ Autophagy Detection Kit according to recommendations. Cells were fixed with $4 \%$ formaldehyde for 20 min at room temp followed by three washes with $1 \mathrm{X}$ assay buffer. Cover slips were then placed on slides with mounting media. Stained cells were analyzed by fluorescence microscopy (Olympus BX51 microscope that has been equipped with the fluorescence illuminator BX-URA2) using an Omega Optical XF100-2 filter for green bandpass with a $475 \mathrm{~nm}$ exciter to image autophagic cells.

\section{Western blot analysis}

A498 cells were plated at $1-2 \times 10^{6}$ cells/ T-75 flask in complete RPMI. After cells were allowed to adhere overnight, cells were treated with 100, $200 \mathrm{nM}$ EA or with $0.1 \%$ DMSO for $48 \mathrm{~h}$ before harvesting. Cells were trypsinized, collected, and resuspended in ice- cold PBS. Cells were lysed in RIPA buffer $(50 \mathrm{mM}$ Tris- $\mathrm{HCl} \mathrm{pH}$ 8.0, 1\% Triton X-100, $150 \mathrm{mM} \mathrm{NaCl,} \mathrm{1mM} \mathrm{EDTA,} \mathrm{0.5 \%}$ Deoxycholate, $0.1 \%$ Sodium Dodecyl Sulfate, $1 \mathrm{mM}$ Sodium Fluoride, $1 \mathrm{mM}$ Sodium Pyrophosphate) in the presence of PMSF and protease inhibitor cocktail. Lysates were clarified by centrifugation for $15 \mathrm{~min}$ at $10,000 \times \mathrm{g}, 4^{\circ} \mathrm{C}$. To the clarified lysate, $4 \times$ NuPAGE LDS sample buffer (Life Technologies) and $0.05 \mathrm{M}$ dithiothreitol were added and samples were heated for $10 \mathrm{~min}$ at $80^{\circ} \mathrm{C}$. Proteins were separated by SDS-PAGE on a $10 \%$ Bis-Tris NuPAGE Gel (Life Technologies) and then transferred to PVDF membranes (Bio-Rad). The PVDF membranes were blocked with 5\% Bovine Serum Albumin (Sigma) in TBS with 0.05\% Tween-20 and probed with antibodies against caspase-3, (diluted 1:1000), LC3B (diluted 1:1000), and B-actin (diluted 1:50,000). Antibodies against AMPK, AKT, ERK and against the corresponding phospho proteins were each diluted 1:1000 except for phospho AKT which was diluted at 1:500. An HRP-conjugated anti-mouse antibody (diluted 1:1000) or HRP-conjugated anti-rabbit antibody (diluted 1:1000;) was used as a secondary detection probe. Bands were visualized using ECL enhanced chemiluminescent substrate (Pierce) and exposed to HyBlot CL film (Denville Scientific). The film was developed with a Kodak film developer.

\section{Cell cycle analysis}

A498 cells were plated at $2 \times 10^{5}$ (control) or at $4 \times 10^{5}$ (EA treated) cells/flask into T-25 flasks in complete RPMI. After cells were allowed to attach overnight, cells 
were treated with $200 \mathrm{nM}$ EA or with $0.1 \%$ DMSO for $45 \mathrm{~h}$. The cells were then trypsinized, washed with icecold PBS, fixed with ice-cold $70 \%$ ethanol at a 1:10 ratio of cell suspension to $70 \%$ ethanol, and stored at $-20^{\circ} \mathrm{C}$ overnight. Cells were washed twice with PBS and then stained with staining solution containing Triton $\mathrm{x}-100$ $(0.1 \% \mathrm{v} / \mathrm{v})$, DNase free RNase $(200 \mu \mathrm{g} / \mathrm{ml})$, PI $(30 \mu \mathrm{g} / \mathrm{ml})$ in PBS for $15 \mathrm{~min}$ at $37^{\circ} \mathrm{C}$. PI content of cells was measured using a FACS Calibur flow cytometer and cell cycle distribution was determined using FlowJo analysis software.

\section{Results}

\section{Examination of viability and determination of apoptosis and necrosis}

Examination of the cytotoxicity of EA against multiple tumor types using the NCI60 cell panel determined that EA was very selectively toxic to $\mathrm{RCC}$ with $\mathrm{GI}_{50}$ concentrations ranging from 10-83 nM in most RCC lines [16]. Our own previous studies have also documented this selectivity [21]. We extended these results by conducting viability studies using one of the most sensitive RCC lines, A498 cells, and treated them with 50 and $100 \mathrm{nM}$ EA from 24 to $48 \mathrm{~h}$. The results of these experiments which measured metabolically active cells, indicated that although cell death was observed by $24 \mathrm{~h}$ at both EA concentrations, the majority of cell death $(>80 \%$ of control) required greater than $24 \mathrm{~h}$ and occurred by $48 \mathrm{~h}$ of treatment (Figure 1A). To confirm these results, as well as to determine the cell death mechanism(s) involved in EA-induced cell death, apoptosis was determined by measuring histone-associated DNA fragments by ELISA in A498 cells treated with $100 \mathrm{nM}$ EA for 24 and $45 \mathrm{~h}$ (Figure 1B). The induction of apoptosis by EA in A498 cells required at least $24 \mathrm{~h}$ for significant levels of apoptosis to occur as no apoptosis was observed at $18 \mathrm{~h}$ (data not shown). Additional studies determined that the EAinduced apoptosis was also dose-dependent (data not shown). To further confirm that EA induced apoptosis in A498 cells, apoptosis was also determined by measuring phosphatidylserine exposure on cells using the Alexa Fluor $^{\circledR} 488$ annexin V/Dead Cell Apoptosis kit followed by flow cytometry. The results of these experiments revealed that EA at $100 \mathrm{nM}$ induced apoptosis in A498 cells at levels well above control by $46 \mathrm{~h}$ of treatment (Figure 1C). The apoptotic cells included Annexin V positive (5.2\%) as well as Annexin V/PI double positive (15.4\%) cells representing early and late stages of apoptosis, respectively. In addition, some necrotic, PI positive, only (4.0\%), cells were also observed. Furthermore, cells treated with a clinically relevant concentration (50 nM) of vincristine, a chemotherapeutic agent known to induce apoptosis in several tumor types [24], induced similar levels of necrosis
(3.6\%), but less than half as much apoptosis $(1.2 \%$ and $7.5 \%$ early and late stages of apoptosis, respectively) as EA in A498 cells. Higher concentrations of vincristine were not tested, thus, it is possible that $100 \mathrm{nM}$ vincristine may have induced similar levels of apoptosis to EA. Overall, our results indicated that EA induced cell death in A498 cells, the majority of which, occurred after $24 \mathrm{~h}$ of treatment, and at least part of this cell death was due to apoptosis.

\section{Analysis of caspase activity}

Having established that EA induced apoptosis in A498 cells, the question remained as to whether caspases were involved in EA-induced apoptosis and if so which ones were involved. To determine if EA induced caspase activation in general, active caspases were measured in A498 cells, treated as indicated in Figure 2A, by using the FLICA reagent (Fluorochrome Inhibitor of Caspases) which binds covalently to only active caspases and allows active caspase detection by fluorescence. The etoposide, VP16, a chemotherapeutic agent known to induce apoptosis in multiple tumor types and known to activate caspases [25], was used as a positive control in these experiments. Because the effective dose of VP16 is in the micromolar range and since RCC cells are not nearly as sensitive to VP16 and other standard chemotherapeutic agents when compared to EA, higher concentrations of VP16 were used in these experiments over EA. While active caspases were detected in cells treated with $200 \mu \mathrm{M}$ VP16, active caspases were not detected in cells treated with $100 \mathrm{nM} \mathrm{EA} \mathrm{(Figure} \mathrm{2A),} \mathrm{a}$ concentration of EA reducing cell viability by $70-80 \%$. To confirm that EA did not induce caspase activation, levels of active caspase-3, an executioner caspase, were also determined. Levels of active caspase-3 were examined by Western Blot analysis in A498 cells treated with $200 \mathrm{nM}$ EA or $0.1 \%$ DMSO for $48 \mathrm{~h}$. The results of this analysis showed no evidence of caspase- 3 activation by EA (Figure 2B) confirming our results using the FLICA reagent (Figure 2A). Similarly, active caspase-9, a caspase frequently activated by anti-cancer agents, was also not detected in A498 cells treated with EA (data not shown). Altogether, our results indicate that apoptosis induced by EA in A498 cells occurs in a caspaseindependent manner.

\section{Detection of autophagy}

The finding that apoptosis induced by EA in A498 cells required at least $24 \mathrm{~h}$, even at concentrations above the $\mathrm{LC}_{50}$ of $75 \mathrm{nM}$ (16), is in contrast to many chemotherapeutic agents such as camptothecin and doxorubicin that require less than $8 \mathrm{~h}$ to induce apoptosis [26,27]. This suggests that multiple events, including possibly metabolic events, are likely required for induction of 

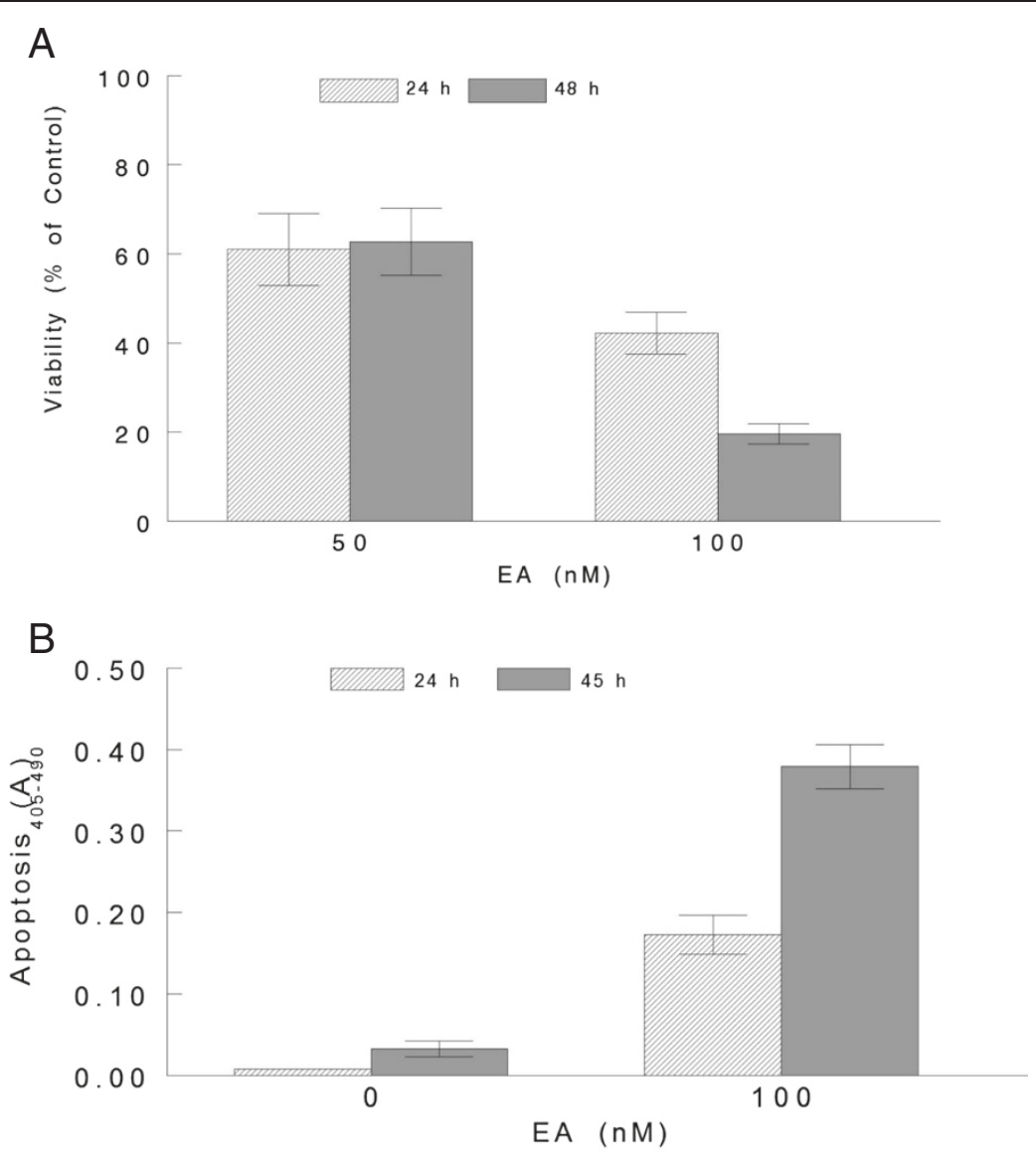

C

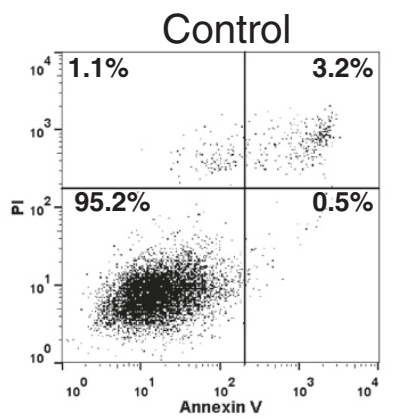

EA

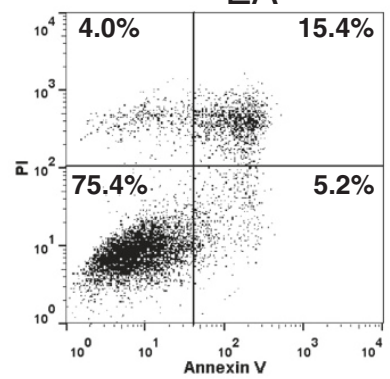

Vincristine

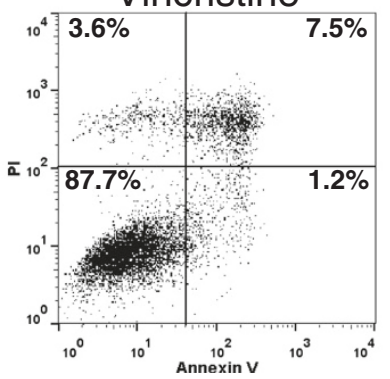

Figure 1 (See legend on next page.) 
(See figure on previous page.)

Figure 1 Induction of cell death by EA in A498 RCC cells. A498 cells were cells were treated with EA at 50 and 100 nM. Control cells received $0.1 \%$ DMSO (vehicle). All conditions were performed in triplicate. Cells were then incubated with additions for 24 or $48 \mathrm{~h}$ before measuring viability using the PrestoBlue ${ }^{\oplus}$ assay (A). A498 cells were treated with $100 \mathrm{nM}$ EA or vehicle for 24 and $45 \mathrm{~h}$ durations. Apoptosis was determined by measuring cytoplasmic histone-associated-DNA-fragments using the Cell Death Detection ELISAPLUS assay kit (B). A498 cells were treated with $100 \mathrm{nM}$ EA or with $0.1 \%$ DMSO (control) for 24 and 46 h. Cells were then trypsinized, washed with ice cold PBS, and stained with Alexa Fluor ${ }^{\circledR}$ 488 annexin $\mathrm{V}$ and $\mathrm{Pl}$ and analyzed by flow cytometry (C).

apoptosis by EA. Cells that are under metabolic stress will often undergo autophagy to generate nutrients for survival [28]. Considering that EA may impose metabolic stress on A498 cells, the induction of autophagy in response to EA was determined. The induction of authophagy was examined by three methods, independently, in A498 cells treated with EA. For the first of these series of experiments, A498 cells were treated with 200 nM EA or $0.1 \%$ DMSO (control) for approximately $45 \mathrm{~h}$. In addition, cells were treated with rapamycin $(500 \mathrm{nM})$,

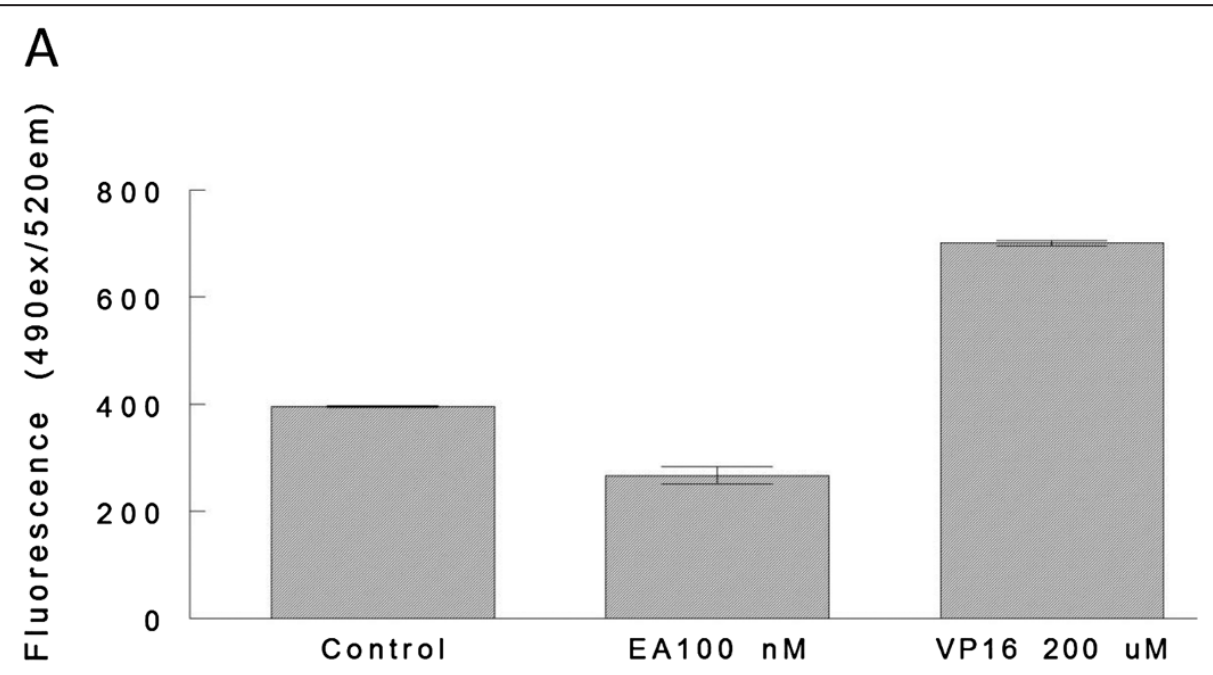

B
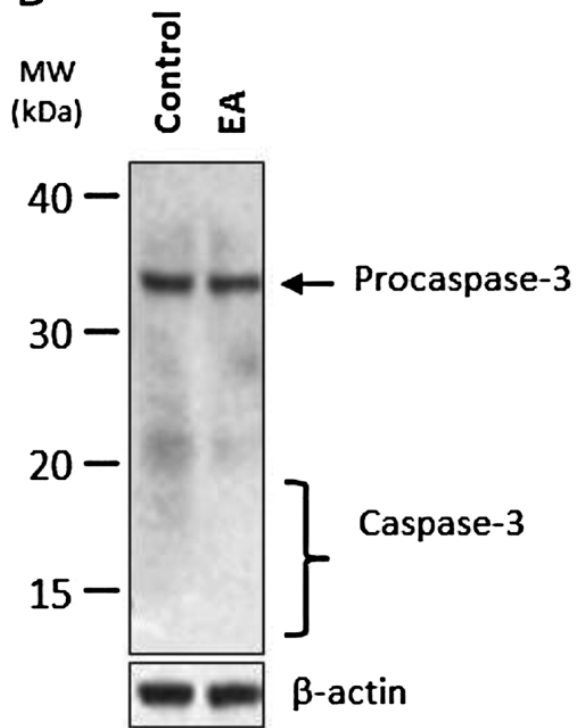

Figure 2 Caspases are not activated in-EA induced cell death. A498 cells cells were treated with 100 nM EA or $0.1 \%$ DMSO (control) for 43 h, or with $200 \mu \mathrm{M}$ etoposide for $24 \mathrm{~h}$. Cells were then harvested and stained with the FLICA reagent which only binds active caspases. Levels of active caspase were then determined by fluorescence (A). A498 cells were treated with $200 \mathrm{nM} \mathrm{EA}$ or with $0.1 \%$ DMSO (control) for $48 \mathrm{~h}$ and protein was extracted. Western blot analysis was performed using an anti-caspase-3 antibody. B-actin was probed as a control for protein loading (B). 
an agent known to induce autophagy [29], for $20 \mathrm{~h}$. Flow cytometry was performed using the fluorescent probe, Cyto-ID ${ }^{\circ}$ Green which primarily stains autolysosomes and earlier autophagic compartments. As presented in Figure 3A, flow cytometry analysis clearly revealed increased staining of cells treated with EA (19.8\% autophagic) or rapamycin (12.6\% autophagic) compared to control (1.9\% autophagic) cells suggesting the induction of autophagy. Importantly, under the conditions of the assay, EA appeared to be at least equal to rapamycin in inducing autophagy in A498 cells. In independent experiments, cells treated with EA as above were also examined by fluorescence microscopy after dual staining with Hoechst nuclear stain and Cyto-ID ${ }^{\circ}$ Green detection reagent. The results displayed in Figure 3B show the increased staining of EA treated cells with Cyto-ID ${ }^{\circ}$ Green (panel d) compared to control cells treated with vehicle (panel c). Specifically, EA treated cells displayed intensely stained punctate structures representing the spherical vacuoles that accumulate in the perinuclear region, or in foci distributed though out the cytoplasm of cells undergoing autophagy $[30,31]$. The upper panels of
A

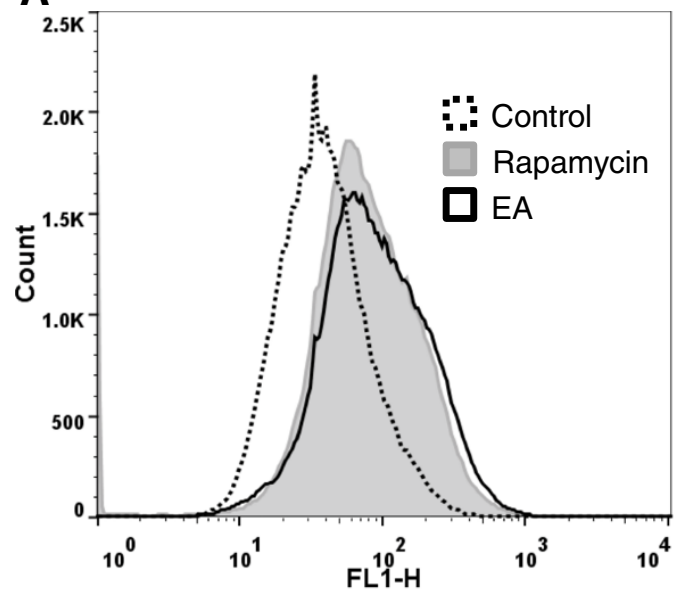

C

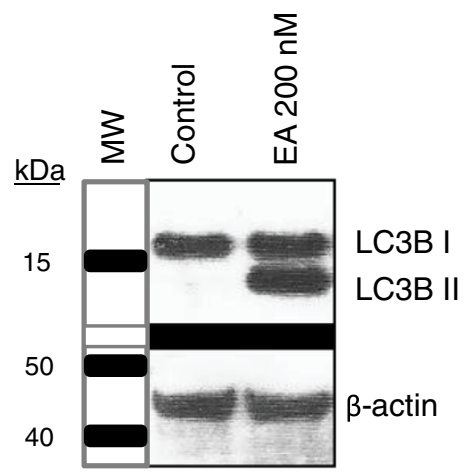

B
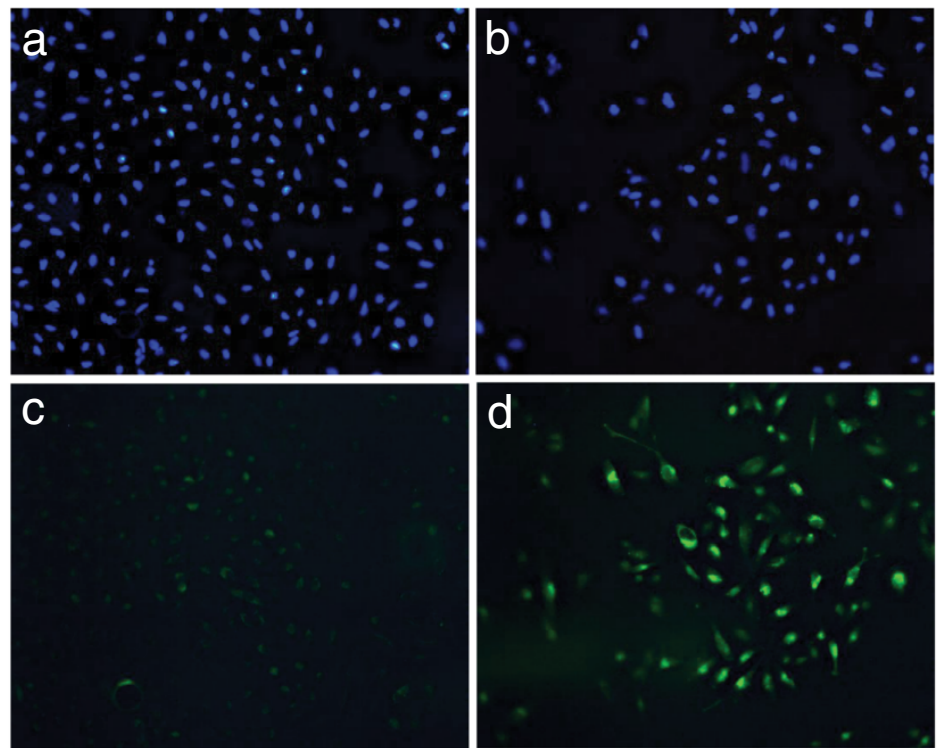

Figure 3 EA induces autophagy in A498 cells. A498 cells were treated with $200 \mathrm{nM}$ EA or $0.1 \%$ DMSO (control) for $46 \mathrm{~h}$ and with $500 \mathrm{nM}$ rapamycin for $20 \mathrm{~h}$. Autophagy was measured by staining autolysosomes and earlier autophagic compartments with the fluorescent probe CytoID ${ }^{\circledast}$ Green. Samples were then analyzed in the green (FL1) channel of the FACS Caliber flow cytometer (A). Cells were treated with $200 \mathrm{nM}$ EA or $0.1 \%$ DMSO (control) for $45 \mathrm{~h}$ and then stained with Hoechst nuclear stain and Cyto-ID ${ }^{\oplus}$ Green detection reagent followed by fixing with $4 \%$ formaldehyde. The stained cells were then analyzed by fluorescence microscopy. Panels a and c show cells treated with $0.1 \%$ DMSO and panels $b$ and $d$ show cells treated with EA. Nuclei are stained in blue. Autolysosomes and earlier autophagic compartments are stained in green (B). A498 cells were treated with $200 \mathrm{nM}$ EA or with $0.1 \%$ DMSO (control) for $48 \mathrm{~h}$ and protein was extracted. Western blot analysis was performed using an anti-LC3B antibody. B-actin was probed as a control for protein loading (C). 
Figure 3B show stained nuclei of control (a) and EA treated cells (b). The use of the Cyto-ID ${ }^{\curvearrowleft}$ Green detection reagent enabled detection and quantification of autophagic cells induced by EA, however, to confirm this action of EA at the molecular level, a well accepted indicator of autophagy [32], the conversion of LC3B-I to LC3B-II, was examined by Western blot analysis in EA treated A498 cells. During autophagy LC3-I is converted to LC3-II by lipidation to allow LC3 to be associated with autophagic vesicles. As shown in Figure 3C, Western blot analysis revealed the conversion of LC3B-I to LC3B-II in EA treated A498 cells but not in control cells confirming the presence of autophagic vesicles in EA treated cells. Importantly, the supplementation of culture medium with nonessential amino acids (NEAA), known inhibitors of autophagy [33,34], decreased the level of autophagic vesicles induced by EA $(100 \mathrm{nM})$ in A498 cells (Figure 4A). The fact that there is a decrease in EA-induced autophagic vesicles upon treatment with NEAA, a known inhibitor of autophagy, implies that EA induces autophagy as opposed to causing an accumulation of autophagic vesicles due to reduced turnover or transport to lysosomes [35]. Interestingly, another well known inhibitor of autophagy, 3-methyladenine (3MA), did not inhibit autophagy and was found to be toxic to A498 cells at concentrations above $2.5 \mathrm{mM}$ (data not shown). This is probably due to the dual role that 3MA has in modulating autophagy in which it can actually induce autophagy depending on the temporal patterns of inhibition of class I and III phosphoinositide 3-kinase [36]. In summary, our results demonstrate that EA induces autophagy in A498 cells which can be inhibited by supplementing cell culture media with NEAA.

\section{Effect of inhibition of autophagy on cell death}

Having demonstrated that EA induces autophagy in A498 cells, the question that arises is whether autophagy is a defense mechanism or a cell death mechanism. To answer this question, both cell viability and levels of apoptosis were determined in independent experiments in which A498 cells were treated with and without NEAA (1X) in the presence and absence of $150 \mathrm{nM} E A$, or with $200 \mu \mathrm{M}$ VP16 for $46 \mathrm{~h}$. As shown in Figure 4B, the viability of cells treated with EA were similar to that receiving EA plus NEAA as determined by the PrestoBlue $^{\curvearrowleft}$ assay. NEAA, alone, had no effect on the cells when compared to control cells receiving vehicle (0.1\% DMSO), whereas, cells treated with VP16 lost viability as expected. These results indicated that inhibition of autophagy did not diminish cell death induced by EA. We then examined the levels of apoptosis in A498 cells treated in the same manner as in the viability experiments. The results of these experiments demonstrated that the levels of apoptosis were similar in cells treated with EA compared to those treated with EA plus NEAA indicating that inhibiting autophagy does not affect the level of apoptosis induced by EA (Figure 4C). It is noteworthy that the level of apoptosis induced by EA appears to be much less than that induced by VP16 (Figure 4B) even though the agents reduce cell viability to similar levels (Figure 4A). Taken together, our results suggest that EA-induced autophagy does not appear to be a cell death mechanism, and is likely a defense mechanism that ultimately fails and cells die by a caspase-independent apoptotic cell death and by necrosis (Figures $1 \mathrm{~B}$ and $\mathrm{C}$ ).

\section{Effect of EA on cell cycle}

In order to gain insight into how EA might regulate cell proliferation in A498 cells, the effect of EA on cell cycle distribution was examined. In these studies, A498 cells were treated with $200 \mathrm{nM}$ EA or with $0.1 \%$ DMSO (control) for $45 \mathrm{~h}$. Cells were then stained after fixing and analyzed by flow cytometry as described under Methods. The results from these experiments demonstrated that cells treated with EA accumulated in the $G_{2}$ phase of the cell cycle indicating a block in $G_{2} / M$ transition (Figure 5).

\section{Effect of EA on activation of AKT, ERK, and AMP-activated kinase}

Because the AKT and ERK signaling pathways drive unrestricted cell proliferation as well as regulate autophagy to obtain nutrients to support rapid growth, they are commonly activated in cancer [37]. Since EA was found to block the cell cycle as well as induce autophagy, it is likely that EA affects these signaling pathways. To examine this possibility, Western blot analysis was performed after treating A498 cells with 100 nM EA or vehicle for increasing times. The results of these experiments revealed reduced levels of phosphorylation of AKT and ERK at both $10 \mathrm{~h}$ and $24 \mathrm{~h}$ of EA treatment indicating inhibition of both kinases by EA (Figure 6). Inhibition of AKT activation by EA is consistent with its ability to inhibit growth and to induce autophagy. In contrast, activation of ERK is usually associated with induction of autophagy [38]. Activation of AMP-activated protein kinase (AMPK) was also examined since this kinase is a known energy sensor and is activated when ATP levels are low due to cell stress resulting in the induction of autophagy [39]. Interestingly, our results did not reveal activation of AMPK at the time points tested (Figure 6).

In summary, our results demonstrate that EA induces cell death in A498 cells by caspase-independent apoptosis and necrosis while inducing autophagy. Inhibition of autophagy does not diminish cell death by EA suggesting that autophagy is not a cell death mechanism and is likely a survival mechanism which ultimately fails. 


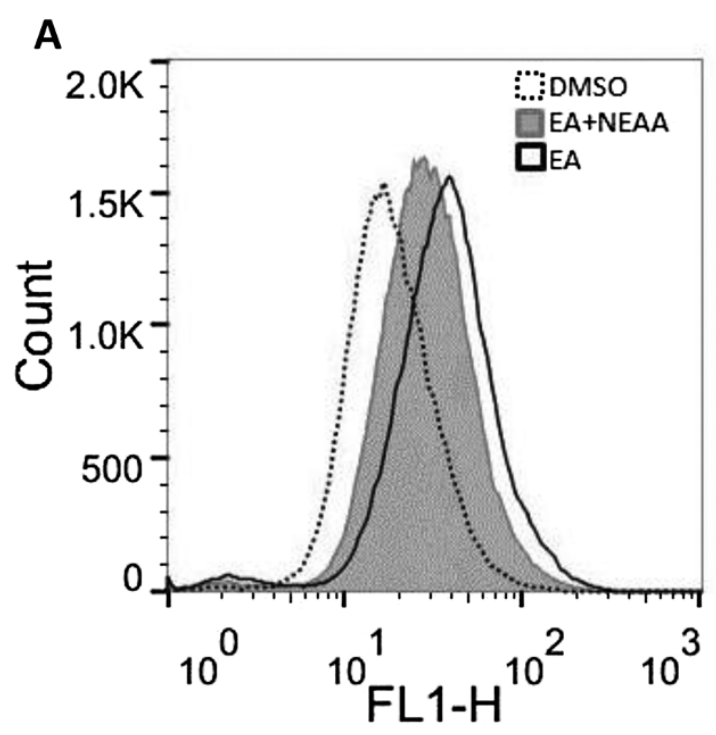

B

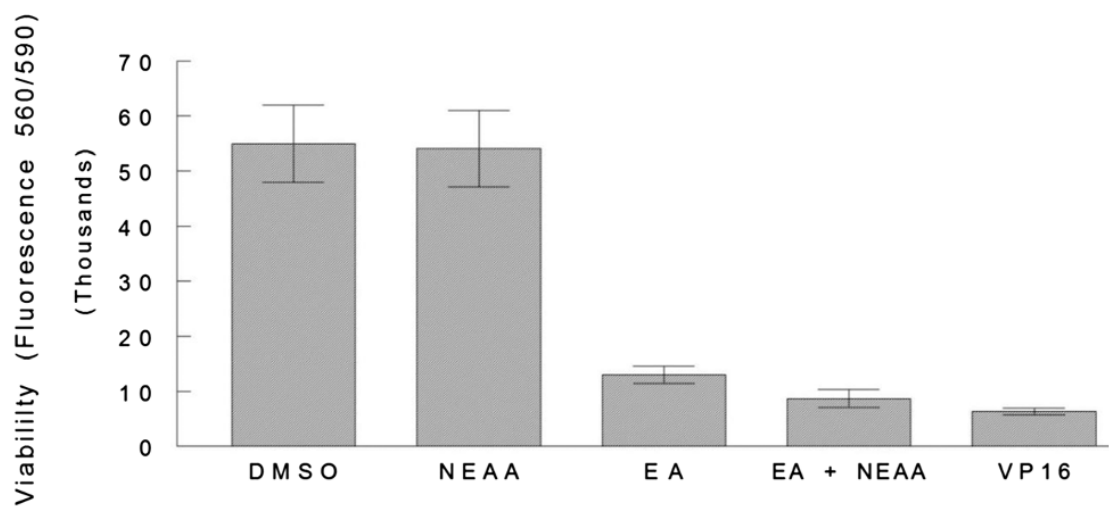

C

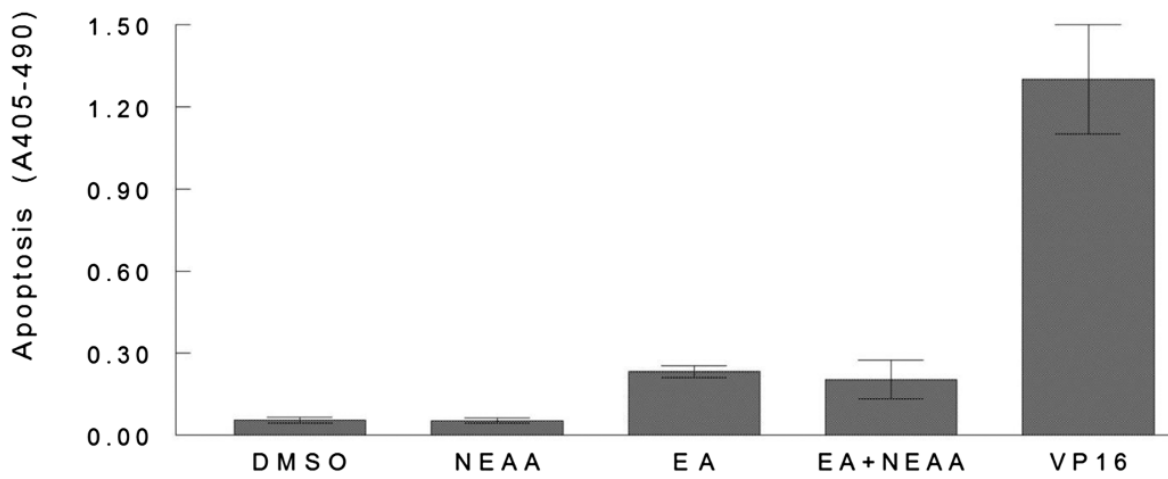

Figure 4 Inhibition of autophagy does not affect EA-induced cell death. A498 cells were cultured in the presence and absence of $100 \mathrm{nM}$ EA or, with EA and 1X NEAA in combination for $44 \mathrm{~h}$. Autophagy was then determined by flow cytometry after staining with Cyto-ID ${ }^{\otimes}$ (A). A498 cells were treated with $150 \mathrm{nM}$ EA, 0.1\% DMSO, 1X NEAA, $200 \mu \mathrm{M}$ VP16 or with $100 \mathrm{nM}$ EA plus 1X NEAA for $46 \mathrm{~h}$. Cell viability was then determined using the PrestoBlue ${ }^{\oplus}$ assay (B). A498 cells were treated as in (B) and then apoptosis was determined by measuring histoneassociated DNA fragments by ELISA (C).

In addition to inducing cell death, EA arrests cells in $\mathrm{G}_{2}$ phase of the cell cycle blocking the G2/M transition. Taken together, our results indicate that cell death by
EA occurs by multiple mechanisms which are likely cell context dependent. Because EA can elicit cell death by multiple mechanisms and can inhibit multiple pathways 

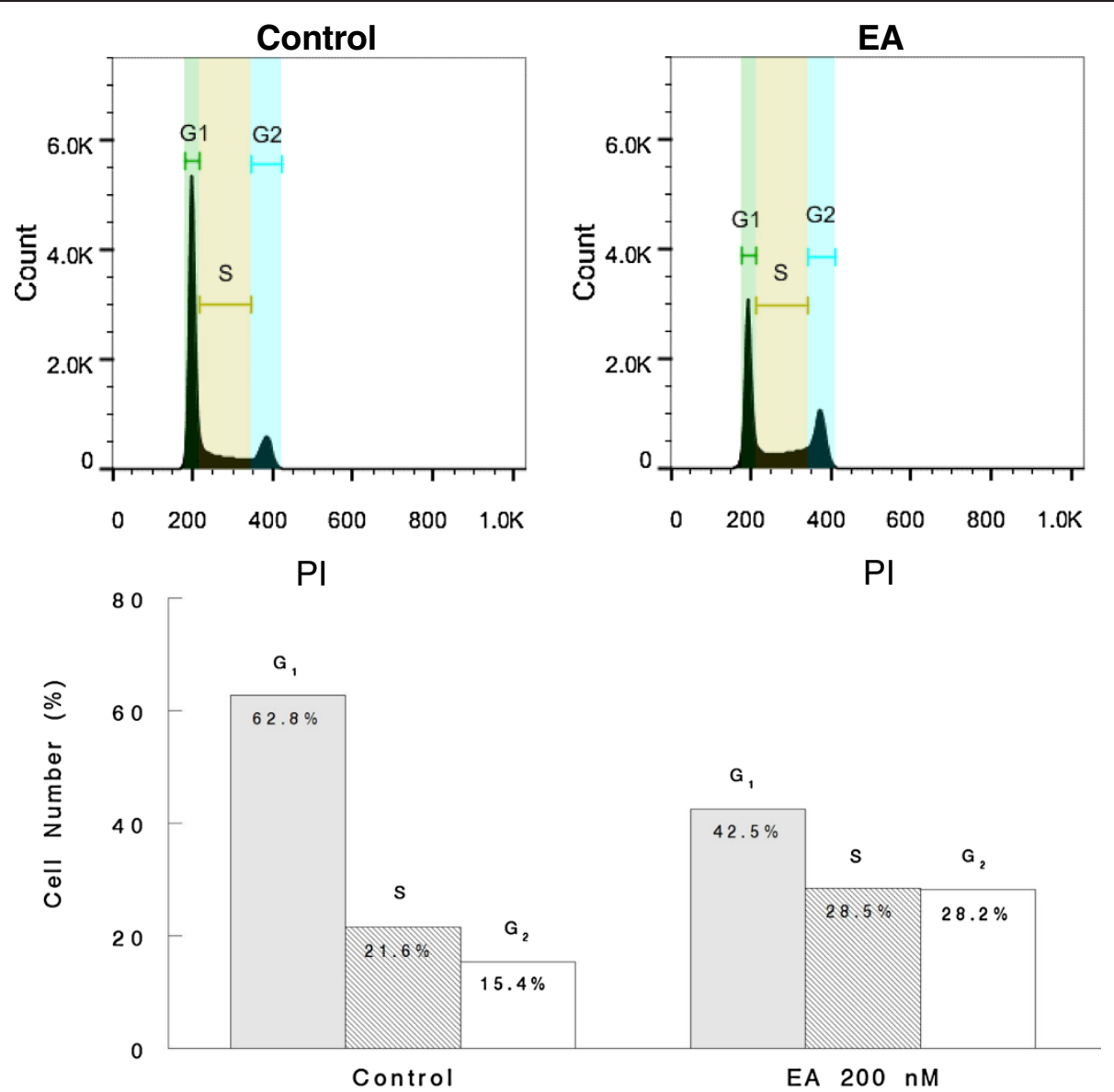

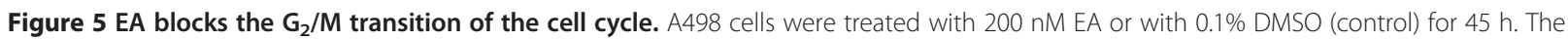
cells were then fixed and stained with PI. The PI content of cells was measured by flow cytometry as described under Methods.

that drive cell proliferation, it has the potential to be an effective chemotherapeutic agent that can bypass chemo-resistance, making it ideal for the treatment of metastatic RCC.

\section{Discussion}

Metastatic RCC is one of the most chemo-resistant cancers for which no curative treatment is available. Hallmarks of this cancer include a highly hypoxic and glycolytic nature and an increased dependency on glucose, all characteristics associated with VHL loss and HIF stabilization which play a central role in the pathogenesis of RCC. However, the limited success of therapeutics targeting the VHL/HIF axis suggests that other molecular alterations also play an important role in the development of RCC. Since pVHL loss and HIFa stabilization are the earliest detectable molecular events in VHL-associated renal tumorigenesis, it is believed that these initial changes trigger other events, both HIFdependent and independent, resulting in progression to RCC. For example, increased hepatocyte growth factor signaling through c-MET, increased susceptibility to
TGF- $\alpha$ /EGF signaling, as well as modifications in extracellular matrix turnover and remodeling are implicated in the pathogenesis of RCC [40]. Clearly, RCC is a complex disease resulting from numerous alterations of genes and pathways that work in concert, indicating that pursuing a single target or pathway will not yield chemotherapeutics with significant efficacy. The best chance for achieving therapeutic efficacy in a disease such as RCC should involve the use of agents that target the multiple pathways which contribute fundamentally to this disease.

Natural products are well known to affect multiple targets and thus have excellent potential as chemotherapeutic agents. The relatively recently identified natural product, englerin (EA), is very unique due to its high selectivity against RCC that is 1000-fold higher than any other cell type [16]. Our results demonstrate that EA induces apoptosis and autophagy in addition to necrosis in A498 RCC cells at nanomolar concentrations. This finding is in contrast to a recent report stating that EA induced necrosis but not apoptosis or autophagy [22]. In this previous study, however, autophagy was most likely 


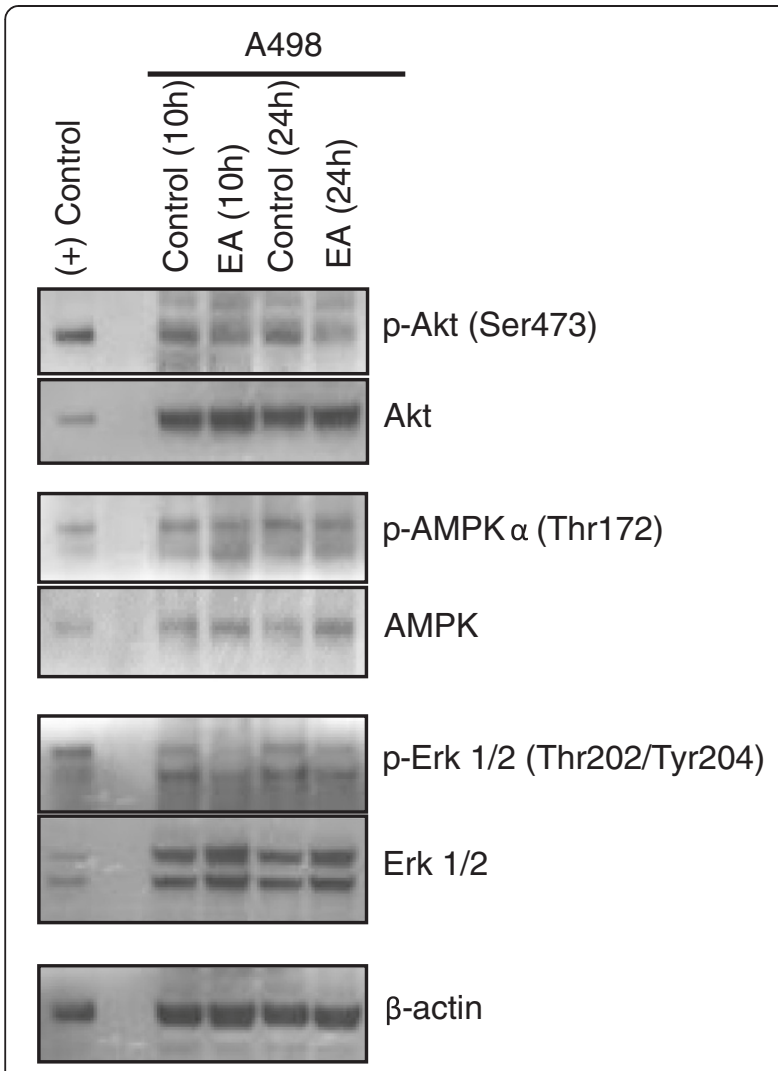

Figure 6 EA inhibits activation of AKT and ERK kinsases. A498 cells were cultured with $100 \mathrm{nM}$ EA or with $0.1 \%$ DMSO (control) for the indicated times and protein was Isolated. Western blot analysis was performed as described under Methods using antibodies against AKT, ERK, and AMPK and their phosphorylated counterparts. B-actin was probed to control for protein loading. (+) control; Jurkat cell extract.

inhibited by the supplementation of culture medium with non-essential amino acids (NEAA), a known inhibitor of autophagy [41], and was thus not observed. Our results confirmed that autophagy induced by EA could be inhibited by NEAA. We further showed that inhibition of autophagy by NEAA did not diminish cell death. This finding is supported by the previous study which showed that RCC cells died under conditions which inhibited autophagy with a sensitivity to EA similar to that observed by us and others [16,21]. For instance, in viability assays in the study by Sulzmaier et al. [22], EA was found to have an $\mathrm{EC}_{50}$ of $53 \mathrm{nM}$ in the presence of NEAA. In the absence of NEAA, the estimated $\mathrm{EC}_{50}$ of EA in A498 cells in our viability assay was $63 \mathrm{nM}$ (Figure 1 and data not shown). Furthermore, the NCI reported $\mathrm{LC}_{50}$ for EA in A498 cells, under conditions not inhibiting autophagy, was $79 \mathrm{nM}$ [16]. Though the $\mathrm{NCI}$ determined $\mathrm{LC}_{50}$ is a somewhat different measure than the $\mathrm{EC}_{50}$, determined by us and Sulzmaier et al. [22], in addition to the assays being different, the fact that these values are not very different regardless of whether autophagy is inhibited, indicates that autophagy does not appear to have much of an effect on cell death. Though autophagy can play a pro-death role when prolonged or in certain developmental conditions [42], in most circumstances, autophagic generation of nutrients prevents or delays cell death [43], thus acting as a survival mechanism. It is, in fact, fairly common for cancer cells experiencing stress of different origin to activate autophagy in an attempt to alleviate stress and survive [44]. It is for this reason, that the autophagic machinery has become a therapeutic target. Inhibiting autophagy in tumor cells exposed to cytotoxic agents often results in increased apoptotic cell death [45]. However, we have not observed this in the context of EA-induced apoptosis as the levels of apoptosis were not altered by the inhibition of autophagy by NEAA (Figure 4). It is not entirely clear what role EA-induced autophagy plays in in A498 cells, but it does not appear to represent a cell death mechanism in this context, and most likely is a survival mechanism that ultimately fails.

Although EA induced apoptosis in A498 RCC cells, it did not appear to be a strong inducer of apoptosis as compared to other agents such as VP16 and camptothecin (Figure 4 and data not shown). Interestingly, the report by Sulzmaier et al. [22] concluded that EA did not induce apoptosis in these cells. However, by analyzing not only external exposure of phosphatidyl serine, but also by examining histone-associated DNA fragments, we found that EA did induce some level of apoptosis in A498 cells. The induction of apoptosis by EA was independent of caspase activation suggesting the involvement of non caspase proteases such as cathepsins and calpains [46]. It is likely that the induction of apoptosis by EA is cell context dependent and, thus, may not be induced in all RCC cells, especially, considering that certain cells may have an apoptotic block. In such a case, EA may induce other mechanisms of cell death such as necrosis as observed by Sulzmaier et al. [22]. Our results indicated that EA also induced necrosis as determined by PI staining (Figure 1C). Taken together, our results indicate that EA can induce cell death by multiple mechanisms and that the predominant mechanism will depend on cell context.

In addition to inducing cell death, EA also induced a block in the G2/M transition of the cell cycle in A498 cells. This indicated that EA may likely regulate cell cycle regulatory genes and affect pathways associated with cell proliferation. In fact, our results indicated that EA inhibited activation of both AKT and ERK, members of two pathways commonly activated in cancer, often together [37], and which are associated with unrestricted cellular proliferation and decreased sensitivity to apoptosis-inducing agents [47]. It is known that inhibition of either pathway alone has a negligible effect on 
tumor growth and survival suggesting that these pathways share downstream targets [48]. The fact that EA can inhibit activation of both pathways suggests that it would be an effective agent in inhibiting tumor growth. This possibility is supported by the findings of a very recent study of EA in athymic mice bearing 786-0 (renal) tumor xenografts [23]. The results of this study demonstrated that EA markedly inhibited tumor growth over a two week period when administered daily at $5 \mathrm{mg} / \mathrm{kg}$ intraperitoneally. This study further showed that tumors excised from the EA-treated mice revealed increased inhibitory phosphorylation of the insulin receptor substrate 1 (IRS1) and decreased activity of the PI3/AKT pathway, in line with our in vitro results in A498 cells. Based on their in vitro results, the authors of this study concluded that EA bound and activated PKC $\theta$ to inhibit insulin signaling while, concurrently, activating HSF1, a known inducer of glucose dependence, thus, starving cells of glucose while promoting glucose addiction. However, because the in vitro binding studies with EA and PKC $\theta$ were indirect without any binding kinetic analyses, it is unclear if PKCO is a primary target of EA. Furthermore, the experiments demonstrating inhibition of glucose uptake by EA were performed using EA at $10 \mu \mathrm{M}$, a concentration of EA approximately 200 -fold higher than its $\mathrm{IC}_{50}$. It is well established that when cells are starved, the energy sensor, AMP-activated protein kinase, becomes activated by phosphorylation resulting in the induction of autophagy. If EA inhibits glucose uptake, it would be expected to result in a higher ADP/ ATP and AMP/ATP ratio and consequent activation of AMPK. Our results, however, did not reveal activation of AMPK by EA at a concentration of $100 \mathrm{nM}$, a concentration that is highly cytotoxic to A498 cells. Hence, it is possible that the effects of EA on glucose uptake may occur at micro molar concentrations that are much higher than required for cell death (nanomolar) and could represent off-target effects. Moreover, as a natural product, EA would be expected to have multiple targets and most likely has targets in addition to PKC $\theta$. Such targets may include those associated with the ER stress since it is well established that ER stress results in the induction of cell death and autophagy [49]. An example of agent that induces autophagy and cell death by inducing ER stress in RCC includes STF-62247 which targets VHL-deficient RCC [50]. EA may target proteins within the Golgi complex analogous to carminomycin I, a natural product with selective toxicity to VHL-deficient CC-RCC [51].

In conclusion, EA induces cell death via multiple mechanisms and likely has multiple cellular targets. The identification of these targets and pathways affected by this unique agent will be invaluable in understanding the high RCC- selectivity of EA and allow development of highly effective chemotherapeutics for the treatment of metastatic RCC, a highly treatment resistant cancer.

\section{Abbreviations \\ EA: Englerin A; RCC: Renal cell carcinoma; HSF1: Heat shock factor 1; VHL: Von Hippel Lindau.}

\section{Competing interests}

The authors declare that they have no competing interests.

\section{Authors' contributions}

AB directed the study, conducted and supervised experiments, and drafted the manuscript. RTW conducted Western blot experiments and well as performed flow cytometry analysis. ALY provided funding and equipment for the project and advised on the project. MBD and ET consulted on project and edited manuscript. In additon, ET provided partial funding for project. All authors have approved the content of the final manuscript.

\section{Acknowledgment}

We gratefully acknowledge Dr. Stoyan Dimitrov for his assistance with the flow cytometry studies.

This work was supported by a fund from Academia Sinica (A. L. Yu) and, in part, by an NIH grant (CA 133002) awarded to Emmanuel Theodorakis.

\section{Author details}

${ }^{1}$ Department of Pediatrics, Hematology/Oncology, University of California, San Diego, CA, USA. ${ }^{2}$ The Genomics Research Center, Academia Sinica, University of California, Taipei, Taiwan. ${ }^{3}$ Stem Cell \& Translational Cancer Research Center, Chang Gung Memorial Hospital, Linkou, Taoyuan, Taiwan. ${ }^{4}$ Department of Chemistry and Biochemistry, University of California, 9500 Gilman Drive, La Jolla, CA 92093, USA.

Received: 27 June 2013 Accepted: 8 August 2013

Published: 20 August 2013

\section{References}

1. Nguyen MM, Gill IS, Ellison LM: The evolving presentation of renal carcinoma in the United States: trends from the Surveillance, Epidemiology, and End Results program. J Urol 2006, 176(6 Pt 1):2397-400.

2. Amato RJ: Renal cell carcinoma: review of novel single-agent therapeutics and combination regimens. Ann Oncol 2005, 16(1):7-15

3. Lane BR, Rini BI, Novick AC, Campbell SC: Targeted molecular therapy for renal cell carcinoma. Urology 2007, 69(1):3-10.

4. Singer EA, Gupta GN, Srinivasan R: Update on targeted therapies for clear cell renal cell carcinoma. Curr Opin Oncol 2011, 23(3):283-9.

5. Gnarra JR, Tory K, Weng Y, Schmidt L, Wei MH, Li H, Latif F, Liu S, Chen F, Duh FM, et al: Mutations of the VHL tumour suppressor gene in renal carcinoma. Nat Genet 1994, 7(1):85-90.

6. Nickerson ML, Jaeger E, Shi Y, Durocher JA, Mahurkar S, Zaridze D, Matveev V, Janout V, Kollarova H, Bencko V, Navratilova M, Szeszenia-Dabrowska N, Mates D, Mukeria A, Holcatova I, Schmidt LS, Toro JR, Karami S, Hung R, Gerard GF, Linehan WM, Merino M, Zbar B, Boffetta P, Brennan P, Rothman $\mathrm{N}$, Chow WH, Waldman FM, Moore LE: Improved identification of von Hippel-Lindau gene alterations in clear cell renal tumors. Clin Cancer Res 2008, 14(15):4726-34.

7. Shuin $T$, Kondo $K$, Torigoe $S$, Kishida T, Kubota $Y$, Hosaka M, Nagashima $Y$, Kitamura H, Latif F, Zbar B, et al: Frequent somatic mutations and loss of heterozygosity of the von Hippel-Lindau tumor suppressor gene in primary human renal cell carcinomas. Cancer Res 1994, 54(11):2852-5.

8. Semenza GL: Regulation of mammalian $\mathrm{O} 2$ homeostasis by hypoxiainducible factor 1. Annu Rev Cell Dev Biol 1999, 15:551-578.

9. Chan DA, Giaccia AJ: Hypoxia, gene expression, and metastasis. Cancer Metast Rev 2007, 26(2):333-339.

10. Baldewijns MM, van Vlodrop IJ, Vermeulen PB, Soetekouw PM, van Engeland $\mathrm{M}$, de Bruïne AP: VHL and HIF signalling in renal cell carcinogenesis. J Pathol 2010, 221(2):125-38.

11. Clark PE: The role of VHL in clear-cell renal cell carcinoma and its relation to targeted therapy. Kidney Int 2009, 76(9):939-945.

12. Najjar YG, Rini BI: Novel agents in renal carcinoma: a reality check. Ther Adv Med Oncol 2012, 4(4):183-194. 
13. Gurib-Fakim A: Medicinal plants: Traditions of yesterday and drugs of tomorrow. Mol Aspects Med 2006, 27(1):1-93.

14. Cragg G, Newmann DJ: Natural products: A continuing source of novel drug leads. Biochim Biophys Acta 2013, 1830(6):3670-95.

15. Calixto JB, Santos ARS, Filho VC, Yunes RA: A review of the plants of the genus Phyllanthus: Their chemistry, pharmacology, and therapeutic potential. Med Res Rev 1998, 18(4):189-296.

16. Ratnayake R, Covell D, Ransom TT, Gustafson KR, Beutler JA: Englerin A, a selective inhibitor of renal cancer cell growth, from phyllanthus engleri. Org Lett 2009, 11(1):57-60.

17. Willot M, Christmann M: Total synthesis: towards artificial terpene cyclases. Nat Chem 2010, 2(7):519-520.

18. Chain WJ: Synthetic strategies toward the guaiane sesquiterpene englerin A. Synlett 2011, 18:2605-2608.

19. Pouwer RH, Richard JA, Tseng CC, Chen DY: Chemical synthesis of the englerins. Chem Asian J 2012, 7(1):22-35.

20. Lu YY, Yao HQ, Sun BF: Progresses in total synthesis of englerin $A$ and biological evaluations of its analogues. Chin J Org Chem 2012, 32(1):1-12

21. Xu J, Caro-Diaz EJ, Batova A, Sullivan SD, Theodorakis EA: Formal synthesis of (-)-englerin $A$ and cytotoxicity studies of truncated englerins. Chem Asian J 2012, 7(5):1052-60.

22. Sulzmaier FJ, Li Z, Nakashige ML, Fash DM, Chain WJ, Ramos JW: Englerin A selectively induces necrosis in human renal cancer cells. PLoS One 2012, 7(10):e48032.

23. Sourbier C, Scroggins BT, Ratnayake R, Prince TL, Lee S, Lee MJ, Nagy PL, Lee YH, Trepel JB, Beutler JA, Linehan WM, Neckers L: Englerin A stimulates PKCO to inhibit insulin signaling and to simultaneously activate HSF1: pharmacologically induced synthetic lethality. Cancer Cell 2013, 23(2):228-37.

24. Huang Y, Fang Y, Wu J, Dziadyk JM, Zhu X, Sui M, Fan W: Regulation of Vinca alkaloid-induced apoptosis by NF-KB/lkB pathway in human tumor cells. Mol Cancer Ther 2004, 3(3):271-277.

25. Chandra D, Choy G, Deng X, Bhatia B, Daniel P, Tang DG: Association of active caspase 8 with the mitochondrial membrane during apoptosis: potential roles in cleaving BAP31 and caspase 3 and mediating mitochondrion-endoplasmic reticulum cross talk in etoposide-induced cell death. Mol Cell Biol 2004, 24(15):6592-607.

26. Wang S, Konorev EA, Kotamraju S, Joseph J, Kalivendi S, Kalyanaraman B: Doxorubicin induces apoptosis in normal and tumor cells via distinctly different mechanisms: intermediacy of $\mathrm{H}(2) \mathrm{O}(2)$ - and p53-dependent pathways. J Biol Chem 2004, 279(24):25535-43.

27. Bergeron S, Beauchemin M, Bertrand R: Camptothecin- and etoposideinduced apoptosis in human leukemia cells is independent of cell death receptor- 3 and -4 aggregation but accelerates tumor necrosis factorrelated apoptosis-inducing ligand-mediated cell death. Mol Cancer Ther 2004, 3(12):1659-69.

28. Degenhardt K, Mathew R, Beaudoin B, Bray K, Anderson D, Chen G, Mukherjee C, Shi Y, Gélinas C, Fan Y, Nelson DA, Jin S, White E: Autophagy promotes tumor cell survival and restricts necrosis, inflammation, and tumorigenesis. Cancer Cell 2006, 10(1):51-64.

29. Pan T, Rawal P, Wu Y, Xie W, Jankovic J, Le W: Rapamycin protects against rotenone-induced apoptosis through autophagy induction. Neuroscience 2009, 164(2):541-51.

30. Zhang DM, Liu JS, Deng LJ, Chen MF, Yiu A, Cao HH, Tian HY, Fung KP, Kurihara H, Pan JX, Ye WC: Arenobufagin, a natural bufadienolide from toad venom, induces apoptosis and autophagy in human hepatocellular carcinoma cells through inhibition of PI3K/Akt/mTOR pathway. Carcinogenesis 2013, 34(6):1331-42.

31. Chan LL, Shen D, Wilkinson AR, Patton W, Lai N, Chan E, Kuksin D, Lin B, Qiu $\mathrm{J}$ : A novel image-based cytometry method for autophagy detection in living cells. Autophagy 2012, 8(9):1371-82.

32. Kabeya Y, Mizushima N, Yamamoto A, Oshitani-Okamoto S, Ohsumi $Y$, Yoshimori T: LC3, GABARAP and GATE16 localize to autophagosomal membrane depending on form-II formation. J Cell Sci 2004, 117(Pt 13):2805-12

33. Meijer AJ: Amino acid regulation of autophagosome formation. Methods Mol Biol 2008, 445:89-109.

34. Kanazawa T, Taneike I, Akaishi R, Yoshizawa F, Furuya N, Fujimura S, Kadowaki M: Amino acids and insulin control autophagic proteolysis through different signaling pathways in relation to $\mathrm{MTOR}$ in isolated rat hepatocytes. J Biol Chem 2004, 279(9):8452-9.
35. Klionsky DJ, Abdalla FC, Abeliovich $H$, et al: Guidelines for the use and interpretation of assays for monitoring autophagy. Autophagy 2012, 8(4):445-544.

36. Wu YT, Tan HL, Shui G, Bauvy C, Huang Q, Wenk MR, Ong CN, Codogno P, Shen HM: Dual role of 3-methyladenine in modulation of autophagy via different temporal patterns of inhibition on class I and III phosphoinositide 3-kinase. J Biol Chem 2010, 285(14):10850-61.

37. She QB, Halilovic E, Ye Q, Zhen W, Shirasawa S, Sasazuki T, Solit DB, Rosen $\mathrm{N}: 4 \mathrm{E}-\mathrm{BP} 1$ is a key effector of the oncogenic activation of the AKT and ERK signaling pathways that integrates their function in tumors. Cancer Cell 2010, 18(1):39-51.

38. Aoki H, Takada Y, Kondo S, Sawaya R, Aggarwal BB, Kondo Y: Evidence that curcumin suppresses the growth of malignant gliomas in vitro and in vivo through induction of autophagy: role of Akt and extracellular signal-regulated kinase signaling pathways. Mol Pharmacol 2007, 72(1):29-39.

39. Hardie DG: AMP-activated protein kinase: an energy sensor that regulates all aspects of cell function. Genes Dev 2011, 25(18):1895-908.

40. Volker HH: Renal cancer: Oxygen meets metabolism. Exp Cell Res 2012, 318(9):1057-67.

41. Seglen PO, Gordon PB, Poli A: Amino acid inhibition of the autophagic/ lysosomal pathway of protein degradation in isolated rat hepatocytes. Biochim Biophys Acta 1980, 630(1):103-1.

42. Das G, Shravage BV, Baehrecke EH: Regulation and function of autophagy during cell survival and cell death. Cold Spring Harb Perspect Biol 2012, 4(6):a008813.

43. Altman BJ, Rathmell JC: Metabolic stress in autophagy and cell death pathways. Cold Spring Harb Perspect Biol 2012, 4(9):a008763.

44. Mathew R, White E: Autophagy, stress, and cancer metabolism: what doesn't kill you makes you stronger. Cold Spring Harb Symp Quant Biol 2011, 76:389-96

45. Hou YJ, Dong LW, Tan YX, Yang GZ, Pan YF, Li Z, Tang L, Wang M, Wang Q, Wang HY: Inhibition of active autophagy induces apoptosis and increases chemosensitivity in cholangiocarcinoma. Lab Invest 2011, 91(8):1146-57.

46. Borner C, Monney L: Apoptosis without caspases: an inefficient molecular guillotine? Cell Death Differ 1999, 6(6):497-507.

47. Steelman LS, Chappell WH, Abrams SL, Kempf RC, Long J, Laidler P, Mijatovic S, Maksimovic-Ivanic D, Stivala F, Mazzarino MC, Donia M, Fagone P, Malaponte G, Nicoletti F, Libra M, Milella M, Tafuri A, Bonati A, Bäsecke J, Cocco L, Evangelisti C, Martelli AM, Montalto G, Cervello M, McCubrey JA: Roles of the Raf/MEK/ERK and PI3K/PTEN/Akt/mTOR pathways in controlling growth and sensitivity to therapy-implications for cancer and aging. Aging 2011, 3(3):192-222.

48. Martinelli E, Troiani T, D'Aiuto E, Morgillo F, Vitagliano D, Capasso A, Costantino S, Ciuffreda LP, Merolla F, Vecchione L, De Vriendt V, Tejpar S, Nappi A, Sforza V, Martini G, Berrino L, De Palma R, Ciardiello F: Antitumor activity of pimasertib, a selective MEK $1 / 2$ inhibitor, in combination with $\mathrm{PI} 3 \mathrm{~K} / \mathrm{mTOR}$ inhibitors or with multi-targeted kinase inhibitors in pimasertib-resistant human lung and colorectal cancer cells. Int I Cancer 2013. Epub ahead of print.

49. Verfaillie T, Salazar M, Velasco G, Agostinis P: Linking ER Stress to Autophagy: Potential Implications for Cancer Therapy. Int J Cell Biol 2010, 2010:930509.

50. Turcotte S, Chan DA, Sutphin PD, Hay MP, Denny WA, Giaccia AJ: A molecule targeting $\mathrm{VHL}$-deficient renal cell carcinoma that induces autophagy. Cancer Cell 2008, 14(1):90-102.

51. Woldemichael GM, Turbyville TJ, Linehan WM, McMahon JB: Carminomycin I is an apoptosis inducer that targets the Golgi complex in clear cell renal carcinoma cells. Cancer Res 2011, 71(1):134-42.

\section{doi:10.1186/1756-9966-32-57}

Cite this article as: Williams et al:: Renal cancer-selective Englerin A induces multiple mechanisms of cell death and autophagy. Journal of Experimental \& Clinical Cancer Research 2013 32:57. 